\title{
THE PIED-BILLED DOBCHICK.
}

\author{
+Prodiceps Carolinensis, Lath.
}

\section{plate CCCClXXXiI.-Male and Female.}

There go the little Dobchicks, among the tall rushes and aquatic grasses that border the marsh. They have seen me, and now I watch them as they sink gently backwards into the deep water, in the manner of frightened frogs. Cunning things! "Water-witches," as they call you, I clearly see your bills, although you have withdrawn all of you save those parts, and sneak off towards yon great bunch of bulrushes. Well, speed on, and may safety attend you! Nature has granted you means of eluding your enemies, and I am heartily glad to see that you have profited by her instructions. I know you can fly too. How happy must you be, to be thus enabled to migrate through the air, instead of being obliged to labour for months with your curiously scolloped feet, in removing from one country to another, as authors say you do. Ah! you have reached a small secluded pool, where you intend to breed in peace and security; there you are, collecting rushes and weeds to form a large matted bed, on which you intend to deposit your pearly eggs. Labour on, mind me not, I am a true friend and admirer of your race. I see that among these plants you have fixed your tenement, in which there will soon be five eggs, which, although tinged with green, will look as if pure white. I wish I knew how many days of constant heat from your bodies it will require to hatch them. Some other time perhaps you may tell me. Miniatures of yourselves I now see swimming gaily, skipping, springing, gliding, dipping, just like yourselves. So, you snatch the crawling bug, and gorge yourselves with leeches, fish, and herbage. How fast your young ones grow, changing from downy to hairy, and again to feathery and silky. On winglets they now cross the clear pool, and crawl on the opposite shore, there enjoying the warmth of the bright sunbeams. September has come; plump and strong seven of you there are; the evening is calm and beautiful; you spread out your wings, reach with some difficulty a proper height, and swift as meteors glide through the air, until, meeting with warmer waters, you alight on them, and there remain for a season.

The Pied-billed Dobchick may be met with in almost every part of the United States, at one season or other: in the south and west during autumn 


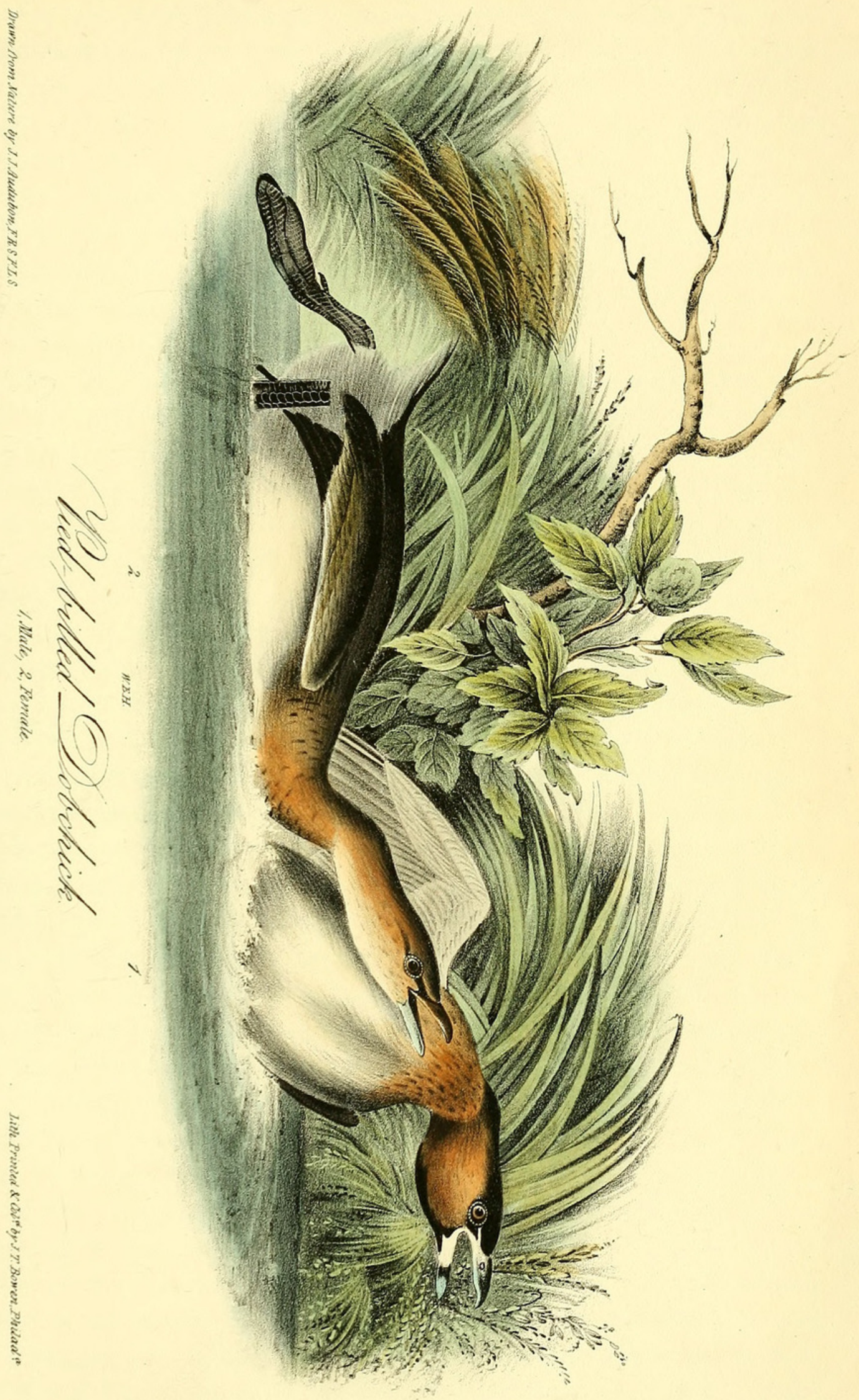

7
$\vdots 0$
0
-10

$=$
0
0
0 

and winter, in the east and north-west in spring and summer, mostly on fresh waters of all descriptions, yet when these are covered with ice, on bays and estuaries, where it searches for shrimps and fry, although under other circumstances such haunts are not congenial to it. It is found in New Brunswick and Nova Scotia, but I did not meet with it in Labrador or Newfoundland.

I had the good fortune, on the 2sth of June, to stumble upon a nest of this bird near the banks of the Wabash river, above Vincennes. It was large for the bird, raised several inches above the muddy and reedy shores of a pond, only a few feet from the water, and composed of decayed weeds, rushes, and earth. On being discovered, the sitting bird slid over the mud, along a path that led directly to the water, in which it immediately dived, and I saw no more of it for about twenty minutes. The eggs, which were five, measured an inch and a quarter, by seven and a half-eighths, were smooth, rather rounded, and of a light greenish-white colour. On breaking one of them, I found it to contain a chick considerably advanced, which induced me to leave the rest untouched, and before I departed I saw the bird, which I believed to be the female, swimming low at a distance. I watched it for some time, but could not discover another, and walked away to allow it to resume its occupation. The nest was fixed among the stalks of strong reeds, but was not attached to any of them. In the month of August, while on the Cayuga lakes, I saw one of these birds with a brood of young about half grown, but could not obtain a single specimen, as they dived with extreme quickness, and eluded all pursuit.

Few birds plunge with more rapidity than this species, which, during submersion, employs its wings, as I had an opportunity of observing while some were passing under a boat when I was in pursuit of them. On the water it is almost impossible to catch them, unless they have been injured in the wing, when they are unable to dive without difficulty. The curious habit which they have of sinking gradually backward in the water, at the sight of an enemy, is very pleasing to observe. Not a ripple do they leave on the spot where they have disappeared, and one unacquainted with them can hardly conceive that a bird could have escaped in so dexterous a manner. My friend Thomas MacCulloch gave me an account of one which, having been observed on a small mill-dam, was pursued by the miller's sons, who, after chasing it fully an hour, could not even drive it on shore. Their father, however, who was as anxious as themselves to see the curious creature, drained the pond, when the little thing was seen crawling over the mud in a manner not unlike that of a turtle. It was now easily caught, as it was not able to rise on wing, the species, it seems, being incapable of spring- 
ing from the ground, and was afterwards given to my young friend, who presented it beautifully prepared to me.

While I was at Philadelphia, my learned and staunch friend the late Dr. Richard Harlan, received two Pied-billed Grebes alive, which had been caught in a fishing-net on Brandywine creek. We placed them in a large tub of water, where we could see all their subaqueous movements. They swam round the sides of the tub in the manner of the Puffin, moving their wings in accordance with their feet, and continued so a much longer time than one could suppose it possible for them to remain under water, coming up to breathe, and plunging again with astonishing celerity. When placed on the carpet, they ran awkwardly half erect, for a distance of a few feet, tumbled over, and scrambled along with the aid of their wings. Nothing could induce them to eat, and after a day or two of captivity, the little creatures were taken to the Delaware, and set at liberty.

This bird retires to rest on the floating beds of rushes met with in ponds, or on the edges of the shores; and in such places you may see it sitting upright, and dressing its plumage in the sunshine. They are extremely unwilling to rise on wing, unless during their migrations, or when chasing each other at the pairing season, which commences in March, when they manifest a good deal of pugnacity. On such occasions, the males fly, dive, and rise again on wing, in the manner of the Foolish Guillemot. While travelling, they pass rapidly through the air, at times at a considerable elevation, when the movements of their wings produce a sound like that of a Hawk stooping on its prey. They are seldom found in parties of more than six or seven. The idea of migrating by water is quite absurd. How long would it take a Dobchick to swim from the mouths of the Mississippi to the head waters of the Ohio; and when arrived there, after six or seven weeks of constant paddling, how is he to proceed farther? Yet it is well known that they breed farther north, and are general on the southern waters early in October.

The food of the Pied-billed Dobchick consists of small fry, plants, seeds, aquatic insects, and snails; along with which they swallow gravel.

They seem to form particular attachments to certain ponds or small lakes, where, until they are closed by ice, you may always observe a pair or a family. Opposite Henderson I regularly saw a couple every autumn, and my friend the Reverend Joнn Bachman has observed a group of them for many winters in a small pond a few miles distant from Charleston. They seem to have a dislike to swift-running streams, and when on them keep to the eddies along the shores. The curious double pectination on the hind part of their tarsi, seems to aid them greatly while sitting upright on the broad leaves of water-lilies, on the surface of which I have observed indented 
impressions after the birds had plunged into the water from them. The young differ in colour from the adult, but the old males and females resemble each other, only the former are larger.

Podiceps carolinensis, Bonap. Syn., p. 418.

Podiceps carolinensis, Pied-bill Grebe, Swains. and Rich. F. Bor. Amer., vol. ii. p. 412. Pied-bill Doвchick, Podiceps carolinensis, Nutt. Man., vol. ii. p. 259.

Pied-bill Doвchick, Podiceps carolinensis, Aud. Orn. Biog., vol. iii. p. 359; vol. v. p. 624.

Male, 14, 23.

Extremely common in autumn on all our Western streams, as well as those of the Atlantic Districts. In winter in the Southern States, as far as Texas. Breeds on the Wabash, and other streams of the interior, to Maine. Migratory.

\section{Adult Male.}

Bill shorter than the head, stout, deep, compressed, tapering. Upper mandible with the dorsal line nearly straight at the base, curved towards the end, the ridge slightly flattened for a short space at the base, narrow in the rest of its extent, the sides convex towards the end, the edges sharp, inflected, the tip obtuse, a little decurved. Nasal groove broad, and extending beyond the middle of the mandible; nostrils elliptical, lateral, sub-medial, pervious. Lower mandible with the angle long and narrow, the sides nearly erect, but convex, the dorsal line very short and sloping upwards, the edges inflected, the tips narrow, the gap-line nearly straight.

Head rather small, oblong, compressed; neck rather long; body depressed. Feet placed far behind, short, stout; tibia bare for a very short space below; tarsus short, much compressed, thin before and behind, anteriorly scutellate, on the sides with large scutelliform scales, posteriorly rough, with a double row of very small scales. Hind toe very small and situated high; fourth toe longest, third a little shorter, second much shorter; anterior toes connected by webs, which beyond the second joint are slit and rounded, the outer edges of the second and fourth furnished with broad lobed membranes; the lobes are marked with parallel grooves, directed a little forwards. Claws of fore toes depressed, that of middle toe resembling a human nail.

Plumage blended, on the forehead with stiff enlarged shafts, as in the Rails, on the back shining and rather hard, as well as on the lower part of the neck anteriorly and laterally, on the rest of the lower parts glossy and hair-like. Wings very small; primary quills curved, the second longest, first slightly shorter, third longer than first; secondary short, broad, rounded, the inner elongated and more tapering. Tail a slight tuft of loose feathers.

Bill pale blue, upper mandible dusky along the ridge, and with the lower 
having a black spot beyond the middle. Iris brown. Feet greyish-black. Upper part of the head and the throat black; neck and sides of the head light greyish-brown, the stiff edges of the feathers on the lower part and sides of the neck greyish-yellow; back brownish-black, as are the inner secondaries; the outer light brown, with a reddish-white spot on the end of the inner web; primaries light brown, dusky at the end. The breast is silvery-white, the abdomen brownish-grey, and the sides mottled with the same.

Length to end of tail 14 inches, to end of wings 12, to end of claws 18; extent of wings 23 ; wing from flexure $4 \frac{10}{12}$; bill along the ridge $\frac{10}{12}$; along the edge of lower mandible $1 \frac{4}{12}$; tarsus $1 \frac{5}{12}$; middle toe 2 , its claw $\frac{4}{12}$. Weight $15 \mathrm{oz}$.

Adult Female.

The female wants the black band on the bill; but is in other respects nearly similar to the male. Weight $13 \mathrm{oz}$.

Male. Mouth 7 twelfths wide; the palate flat, with two longitudinal ridges on each side; the anterior part with three. The tongue is 10 twelfths long, slender, slightly concave above, trigonal, tapering to a thin horny point. EEsophagus 8 inches long, $\frac{1}{2}$ inch in width along the neck. The proventriculus, $b c$, forms a very large sac, as in the other species, 10 twelfths in width; but the stomach, $c d$ e $f$, although still very large, is more muscular in structure, and approaches in character to a true gizzard. It is of an irregularly elliptical form, $1 \frac{3}{4}$ inches long, $1 \frac{1}{4}$ inches broad; there are distinct lateral muscles 5 twelfths thick, a very prominent inferior muscle, $e$, and large oblong tendons. The epithelium is very thick, dense, tough, with remarkably strong longitudinal rugæ, transversely fissured, and also lining the large pyloric cavity, $f$, which is 8 twelfths

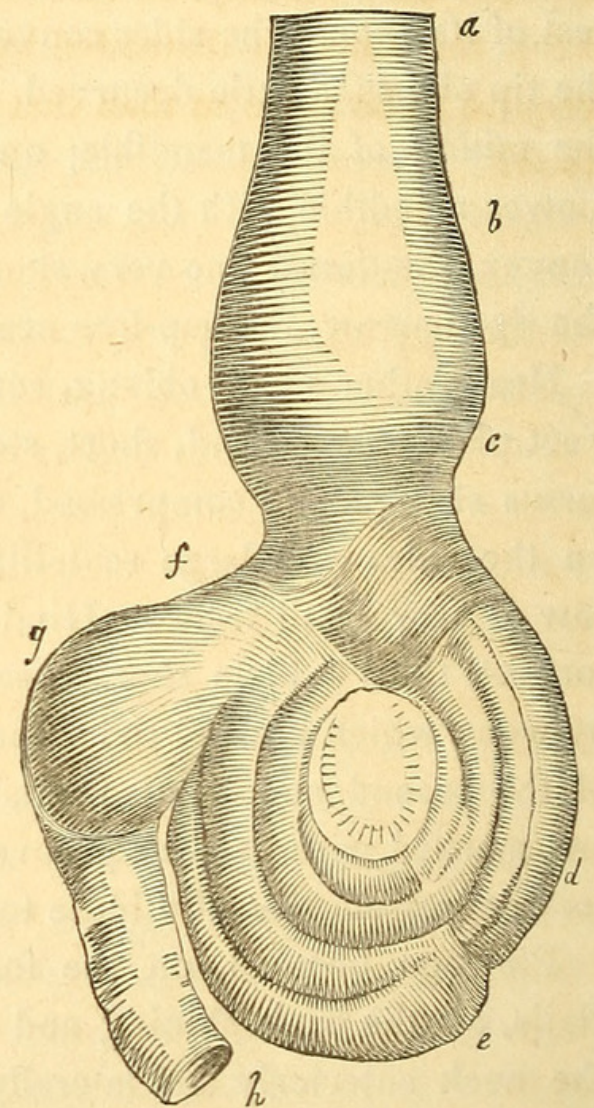
in extent. The proventricular glands are exceedingly large, those in the middle being 3 twelfths long, and $\frac{1}{4}$ twelfth broad; they form a belt $1 \frac{1}{4}$ inches in breadth. The intestine forms 8 folds, and measures 31 inches in length; its width at the upper part is $3 \frac{1}{4}$ twelfths, at the lower 3 twelfths. 
The cœca are only 3 twelfths long, and 1 twelfth broad. The cloaca is globular, and of moderate size.

The trachea is 5 inches 10 twelfths long, much flattened; $1 \frac{3}{4}$ twelfths in breadth, toward the lower part 2 twelfths, and lastly contracted to $1 \frac{1}{2}$ twelfths; the rings 150 . The bronchi differ in this species from the rest in being composed of distinctly separated cartilaginous half rings, 15 in number. The muscles as in the other species.

In another individual, a female, the stomach is of a regularly elliptical form, 1 inch 9 twelfths long, $1 \frac{1}{2}$ inches in breadth; the muscular coat of moderate thickness, composed of strong fasciculi; the epithelium thinner and more corrugated. The stomach contains a great quantity of feathers, scales of fishes, numerous elytra of aquatic coleoptera, and a fish 3 inches long, and 11 twelfths in depth.

It is very remarkable, and equally singular, that all the Grebes should have the stomach distended with feathers. These bodies being indigestible, and not the remains of objects devoured, for none of these birds prey upon birds, must be swallowed for the purpose of aiding digestion; but in what manner they accomplish this object is not easily determinable. They may keep the stomach distended by their elasticity, but why should that organ require to be more so than that of the Divers, which live on the same sort of food? 


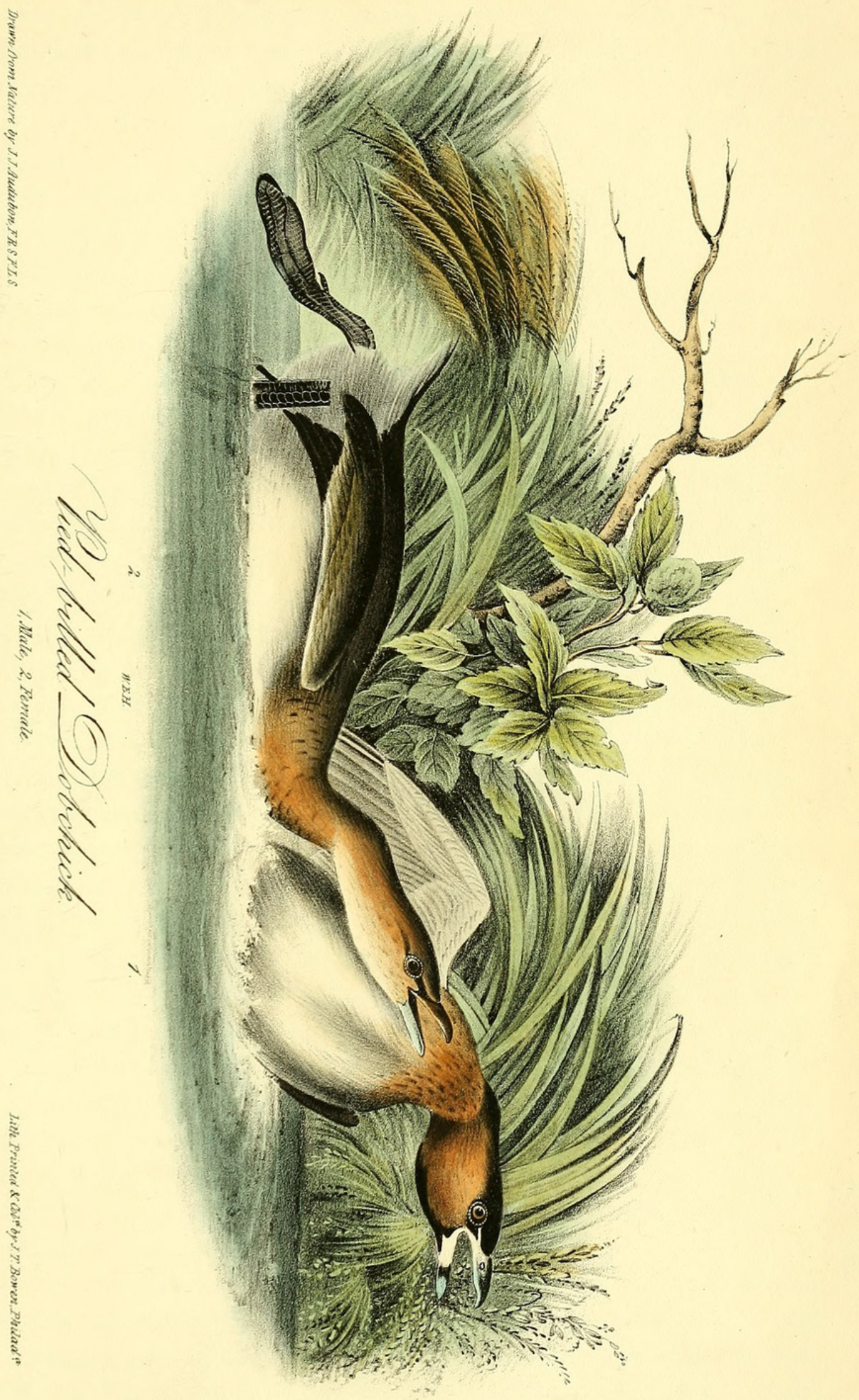

7
$\vdots 0$
0
-10

$=$
0
0
0 


\section{$2 \mathrm{BHL}$ Biodiversity Heritage Library}

Audubon, John James. 1844. "The Pied-Billed Dobchick., Podiceps carolinensis, Lath. [PI. 483]." The birds of America : from drawings made in the United States and their territories 7, 324-329. https://doi.org/10.5962/p.319600.

View This Item Online: https://www.biodiversitylibrary.org/item/124981

DOI: https://doi.org/10.5962/p.319600

Permalink: https://www.biodiversitylibrary.org/partpdf/319600

\section{Holding Institution}

Smithsonian Libraries

\section{Sponsored by}

Biodiversity Heritage Library

\section{Copyright \& Reuse}

Copyright Status: NOT_IN_COPYRIGHT

This document was created from content at the Biodiversity Heritage Library, the world's largest open access digital library for biodiversity literature and archives. Visit BHL at https://www.biodiversitylibrary.org. 